Correspondence to: Dr M H Marion

1 Quinn N, Hallet $M$. Doses standardisation of botulinum toxin. Lancet 1989;i:964.

2 Schantz EJ, Johnson EA. Dose standardisation of botulinum toxin. Lancet 1990;335:421

3 Brin MF, Blitzer A. Botulinum toxin: dangerous terminology errors. Fournal of the Royal Society of Medicine 1993;86:493-4.

4 Marsden CD. Botulinum toxin: dangerous terminology errors. Fournal of the Royal Society of Medicine 1993;86:494.

5 Pickett AM, Hambleton P. Dose standardisation of botulinum toxin. Lancet 1994;344: tion of

6 Hambleton P, Pickett AM. Potency equivalence of botulinum toxin preparations. fournal of the Royal Society of Medicine 1994;87:719.

\section{Changes of diffuse neurofibrillary tan- gles with calcification (DNTC) in a woman without evidence of dementia}

Kosaka has proposed the term "diffuse neurofibrillary tangles with calcification" (DNTC) for a form of presenile dementia characterised by cortical dementia, neurofibrillary tangles, and neuropil threads, but lacking plaques in the cerebral cortex, and coexisting with Fahr's type calcification and temporal or temporofrontal atrophy with neuronal loss and astrocytosis. ${ }^{1} \mathrm{We}$ have recently encountered a similar pathological change, however, in a woman with no history of dementia. As a result, five other cases of idiopathic intracerebral calcification were reviewed, specifically to determine whether neurofibrillary tangles were present.

The recent case involved a 64 year old woman whose sudden death was attributed to ischaemic heart disease. Her brain, which weighed $1300 \mathrm{~g}$, had calcified masses up to $2 \mathrm{~cm}$ in diameter in the cerebellum, with further patches of calcification in the cere-

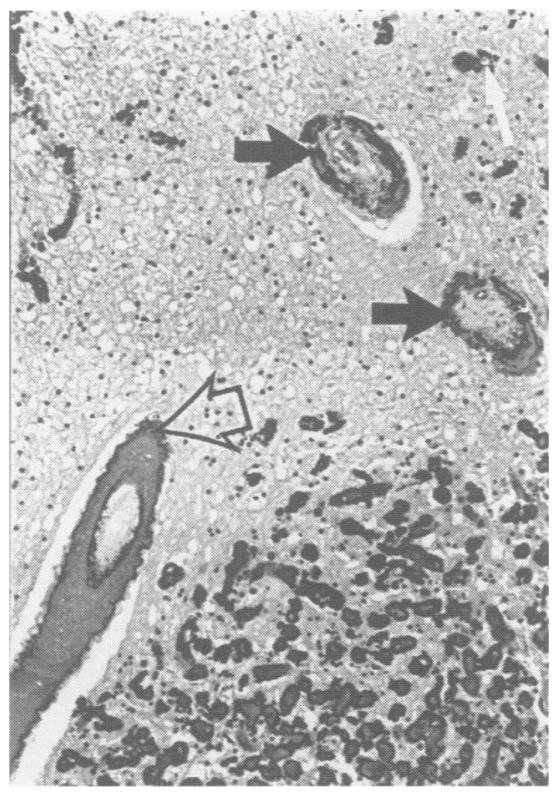

Figure 1 Calcification in the cerebellum within the media (open black arrow) and adventitia (solid black arrows) of arterioles, and around capillaries (white arrow). Also note calcospherules, bottom right

(haematoxylin and eosin $\times 60$ ).

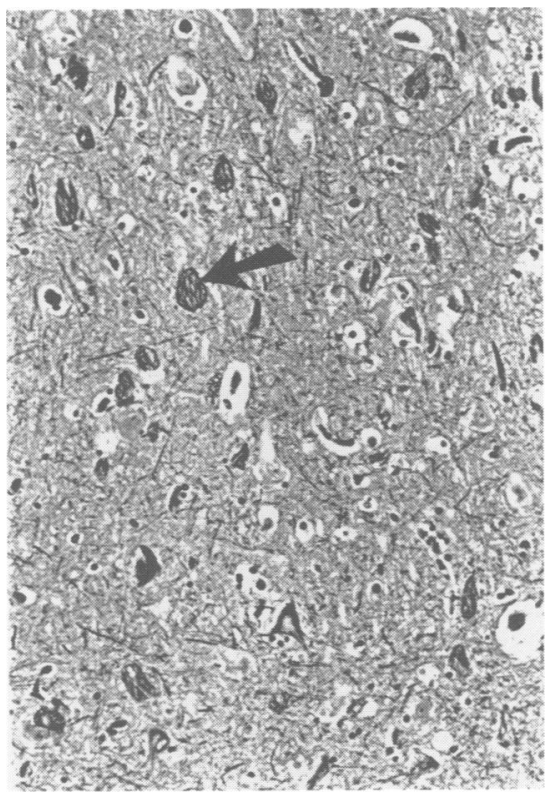

Figure 2 Neurofibrillary tangles in the hippocampus with an absence of plaques (a well formed tangle is arrowed;

Hicks/Gallyas × 75).

bral hemispheres. Moderate generalised cerebral atrophy particularly affected the temporal lobes, and the ventricles seemed mildly dilated.

Histological examination showed calcospherules and larger concretions, predominantly in the dentate nucleus, central cerebellar white matter, cerebellar cortical granular layer, and basal ganglia, often related to capillaries. In addition, there was continuous calcification in the media and adventitia of many small arteries and veins in these areas (fig 1). The brain stem was not affected. Spongiosis and gliosis accompanied pronounced neuronal loss in the atrophic temporal cortex, these features being most obvious within the superficial laminae. Many neurofibrillary tangles (fig 2), which were tau positive, were present, but there were virtually no plaques. Tangles, without plaques, were also noted in the hippocampus and parahippocampal cortex. Otherwise neurons seemed unaffected, even in areas of dense calcification.

Subsequent enquiry confirmed that there was no history of neurological impairment or relevant past illness. Specifically, there had been no evidence of dementia or movement disorder. This was corroborated by her apparent state of well being - she had lived alone and was well nourished and of neat appearance.

Review of archive material from the past 14 years yielded five further cases of Fahr's type calcification, two in males (aged 45 and 34 years) and three in females (aged 60,30 , and 6 years). All showed appreciable calcification of Fahr's type, but no evidence of neurofibrillary tangle formation. One patient had had psychosis and depression, but none had shown evidence of dementia during life.

Extensive calcification of the cerebellum and cerebrum has been recorded in patients with hypoparathyroidism and also as a result of high lead exposure, ${ }^{23}$ but a review of the medical literature failed to find an association between the calcification and tangle formation or dementia in such cases. One paper did refer to unexplained intracranial calcification in patients also with dementia, and an association with hypothyroidism was proposed. ${ }^{4}$ Extensive neuropathological examination of these cases was not, however, performed.

Diffuse neurofibrillary tangles with calcification (DNTC) seems to be a rare entity, largely confined to Japan, with only 16 cases recorded in the medical literature. ${ }^{1}$ The macroscopic and microscopic features in our 64 year old patient very closely match the findings described in patients with the postulated dementing illness DNTC, ${ }^{15}$ except that the brain was rather heavier than in recorded cases. The patient did not manifest dementia during life, however: nor was there any suggestion of the movement disorders that may accompany DNTC. ${ }^{15}$ Therefore, it is proposed that the term diffuse neurofibrillary tangles with calcification (DNTC) encompasses a specific constellation of neuropathological changes, but is not necessarily associated with dementia. H K GRIEVE Department of Pathology, University Medical Buildings, Foresterhill,

Aberdeen AB9 2ZD, UK

Correspondence to: Dr Langlois.

1 Kosaka K. Diffuse neurofibrillary tangles with calcification: a new presenile dementia. $f$ Neurol Neurosurg Psychiatry 1994;57:594-6.

2 Fullop $M$, Zeifer B. Case report: extensive brain calcification in hypoparathyroidism. Am f Med Sci 1991;302:292-5.

3 Benson MD, Price J. Cerebellar calcification and lead. 7 Neurol Neurosurg Psychiatry 1985;48:814-8.

4 Burke JW, Williamson BRJ, Hurst RW. "Idiopathic" cerebellar calcifications: association with hypothyroidism? Radiology 1988; 167:533-6.

5 Shibayama H, Kobayashi $H$, Nakagawa $M$ Yamada K, Iwata $\mathrm{H}$, Iwata $\mathrm{K}$, et al. Non-Alzheimer non-Pick dementia with Fahr's syndrome. Clin Neuropathol 1992;11: 237-50.

Increased serum concentrations of protein S-100 after minor head injury: a biochemical serum marker with prognostic value?

Protein S-100 is a calcium binding protein, synthethised in astroglial cells in all parts of the CNS. High concentrations of protein S100 in CSF have been found in patients with different neurological diseases or injuries. ${ }^{1}$ Only very low concentrations of this protein are normally present in serum, whereas high serum concentrations indicate damage to glial cells and blood brain barrier dysfunction. To predict and prevent an eventual development of symptoms after concussion, there is a need for an early sensitive marker of brain damage in patients with negative radiological examination after minor head injury. Most patients with minor head injury have a good outcome, but in $15 \%$ to $50 \%$ symptoms develop after concussion. ${ }^{2}$ After minor head injury CT has not shown an association between neuroradiological abnormalities and the development of symptoms, but on a microscopic level, there is evidence for organic brain lesions. ${ }^{3}$ 
Fifty consecutive patients aged 6 to 88 (mean 31 ) years ( 35 male, 15 female) with isolated minor head injury were investigated. The examination at admission included clinical neurological investigation and classification according to the Glasgow coma scale (GCS). Brain CT was performed within 12 hours in all cases. The following criteria were required: (a) head injury with loss of consciousness, (b) a clinical condition equivalent to a GCS score of 14-15 at examination, $(c)$ absence of focal neurological deficits, and (d) no signs of intracranial lesion on CT. As a contro group, 18 patients aged 2-67 (mean 33) years (14 male, four female) with severe head injury were included in the study. All had a GCS score $\leqslant 8$ at admission, and the first CT showed intracerebral contusions.

Two blood samples were collected for analysis of protein S-100, the first as early as possible after the trauma (at admission), and the second 12 hours after injury. The S-100 protein serum concentrations were analysed with a commercially available two site immunoradiometric assay kit (Sangtec Medical AB, Bromma, Sweden). Samples were analysed in duplicate and those with more than $10 \%$ coefficient of variation were rejected. A value of $0.5 \mu \mathrm{g} / 1$ or more was considered pathological.

Forty two patients with minor head injury were followed up at nine months after head injury, including a personal interview. The patients were asked about 12 of the most frequent complaints described after head injury with concussion ${ }^{2}$ : headache, impaired memory, fatigue, dizziness, irritability, impaired concentration, insomnia, tinnitus, hearing defect, depression, anxiety, and double vision.

The first sample for measurement of protein $S-100$ was drawn between 0.5 and 9.0 (mean 3.2) hours after the trauma. In 37 patients a second sample was drawn 12 hours after injury. Ten patients had increased concentrations (mean $1 \cdot 1$, range $0.5-2.5 \mu \mathrm{g} / \mathrm{l})$ in the first sample. Of the 37 second samples, four showed concentrations $\geqslant 0.5 \mu \mathrm{g} / \mathrm{l}$. All showed a decrease

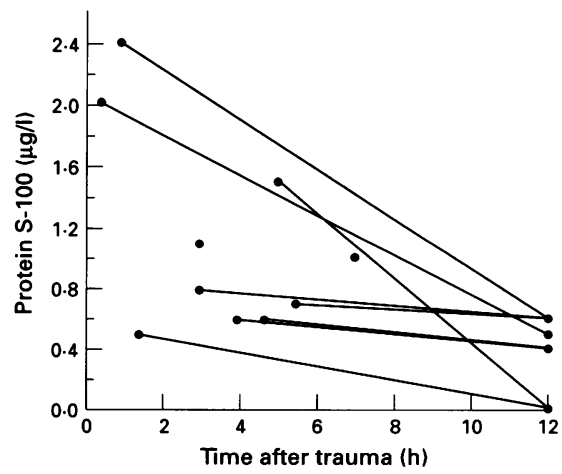

Ten of 50 patients showed increased concentration of protein $S-100$ within the first hours after minor head injury. Values $\geqslant 0.5 \mu \mathrm{g} / \mathrm{l}$ were considered pathological. Measurements performed 12 hours after the trauma showed a decrease in eight patients. In two patients, only one sample was drawn. Four patients showed serum values $\geqslant 0.5 \mu \mathrm{g} / \mathrm{l} 12$ hours after injury.

Incidence of symptoms after concussion after minor head injury in 42 patients

\begin{tabular}{llll}
\hline & $\begin{array}{l}\text { Protein } \\
S-100 \geqslant 0.5 \mathrm{mg} / \mathrm{l} \\
(n=9)\end{array}$ & $\begin{array}{l}\text { Protein } \\
S-100<0.5 \mathrm{mg} / \mathrm{l} \\
(n=33)\end{array}$ & $\begin{array}{l}\text { Total } \\
(n=42)\end{array}$ \\
\hline Symptoms after concussion & $6(67 \%)$ & $12(36 \%)$ & $18(43 \%)$ \\
Persistent symptoms at nine months & $2(22 \%)$ & $9(27 \%)$ & $11(26 \%)$ \\
\hline
\end{tabular}

compared with the first measurement (figure). Nine of 42 patients followed up showed increased serum concentrations of protein S-100 at admission. The overall incidence of symptoms after concussion was 18 of 42 patients $(43 \%)$. Six of the nine patients $(67 \%)$ with an increase in protein S-100 reported symptoms after concussion. Of 33 patients without an increase in protein S-100, 12 (36\%) reported symptoms after concussion. Persistent symptoms at follow up were reported by two of the nine patients with an increase in protein $\mathrm{S}-100$ $(22 \%)$, and nine of the 33 patients $(27 \%)$ without an increase (table). In both groups, the most often reported symptoms were fatigue, headache, impaired concentration, dizziness, and impaired memory. The mean number of symptoms reported per patient was 1.4 in patients with an increase in protein S-100 and 1.2 in patients without an increase. All 18 patients with severe head injury showed serum concentrations of protein $S-100 \geqslant 0.5$ (mean $7 \cdot 0$, range $0.5-15.7$ $\mu \mathrm{g} / \mathrm{l}$ ) in samples drawn within 12 hours after the head trauma.

In the present report, the total incidence of symptoms after concussion was in accordance with previous studies. ${ }^{2}$ Increased serum concentrations of protein S-100 were detected in 10 of the 50 samples drawn within the first hours after minor head injury, and in four out of 37 assessed 12 hours after injury. The patient with the highest protein $\mathrm{S}-100$ value $(2.4 \mu \mathrm{g} / 1$ one hour after trauma) reported headache and fatigue lasting four weeks. Sixty seven per cent of the patients with $\mathrm{S}-100$ increase reported complaints after the injury, whereas such symptoms appeared in only $36 \%$ of the patients without an increase in protein $\mathrm{S}-100$. No difference was found for persistence of symptoms at follow up.

Persson et al reported three patients with severe head injury and persisting coma; two showed increased concentrations of protein S-100 in CSF. ${ }^{4}$ In our study, a protein S100 serum concentration $\geqslant 0.5 \mu \mathrm{g} / 1$ was detected in all 18 patients with severe head injury with contusions verified by CT, indicating cellular leakage of the protein with disruption of the blood brain barrier. Furthermore, increased serum concentrations of protein S-100 were found in cases with normal CT, suggesting a protein leakage through the blood brain barrier due to cell injury, also in patients with minor head injury. Creatine kinase BB and neuron specific enolase have been found in patients with minor head injury. ${ }^{5}$ These biochemical markers are, however, present in tissues other than brain. As patients with head injuries often show thoracic, abdominal, and skeletal trauma, enzyme changes in multitrauma cases may be less specific for brain damage. Protein S-100 is known to be unique to the nervous system. After glial tissue damage followed by disruption of the blood brain barrier, it is reasonable to fore- see the release of this organ specific marker in serum.

Brain CT is not very sensitive in evaluation of diffuse brain damage in patients with minor head injury, ${ }^{6}$ and MRI provides more information concerning primary brain damage. The greater availability of CT, however, implies that CT will remain the standard initial radiological investigation for head injury. Hence, a biochemical serum marker would be of particular value in clinical practice, to show the presence and eventual extent of diffuse brain damage. Even a slight increase of the protein S-100 concentration in serum could be interpreted as a sign of cell damage and reduced integrity of the blood brain barrier. This may improve our present poor understanding of the pathophysiology of brain damage in those patients who sustain symptoms after concussion despite normal radiological findings.

We gratefully thank Sangtec Medical AB, Bromma, Sweden.

TOR INGEBRIGTSEN Department of Neurosurgery, Department of Neurosurgery,
University Hospital of Tromsi, Norway BERTIL ROMNER POUL KONGSTAD Department of Neurosurgery, University Hospital of Lund, Sweden
BODIL LANGBAKK Department of Clinical Chemistry, University Hospital of Tromse, Correspondence to: Dr T Ingebrigtsen, Depart-
ment of Neurosurgery, University Hospital of ment of Neurosurgery, University
Tromsø, 9038 Tromsø, Norway.

1 Sindic CJM, Chalon MP, Cambiaso CL, Laterre EC, Masson PL. Assessment of damage to the central nervous system by determination of $S-100$ protein in the cerebrospinal fluid. F Neurol Neurosurg Psychiatry 1982;45:1130-5.

2 Middelboe T, Andersen HS, Birket-Smith $M$, Friis ML. Minor head injury: impact on general health after 1 year. A prospective general health after 1 year. A prospective
follow-up study. Acta Neurol Scand 1992; 85:5-9.

3 Oppenheimer DR. Microscopic lesions in the brain following head injury. $f$ Neurol Neurosurg Psychiatry 1968;31:299-306.

4 Persson L, Hårdemark HG, Gustafsson J, et al. S-100 protein and neuron-specificenolase in cerebrospinal fluid and serum: markers of cell damage in human central nervous tissue. Stroke 1987;18:911-8.

5 Skogseid IM, Nordby HK, Urdal P, Paus E, Lilleaas F. Increased serum creatine kinase $\mathrm{BB}$ and neuron specific enolase following head injury indicates brain damage. Acta Neurochir 1992;115: 106-11.

6 Shacford SR, Wald SL, Ross SE. The clinical utility of computed tomographic scanning and neurologic examination in the management of patients with minor head injuries. f Trauma 1992;33:385-94. 